\title{
EMPLOYING U.S. NAVY HOSPITAL SHIPS IN SUPPORT OF SOFT POWER PROJECTION
}

\author{
BY \\ CAPTAIN MICHAEL A. SOKOLOWSKI \\ United States Navy
}
DISTRIBUTION STATEMENT A:
Approved for Public Release.
Distribution is Unlimited.

\section{USAWC CLASS OF 2011}

This SRP is submitted in partial fulfillment of the requirements of the Master of Strategic Studies Degree. The views expressed in this student academic research paper are those of the author and do not reflect the official policy or position of the Department of the Army, Department of Defense, or the U.S. Government.

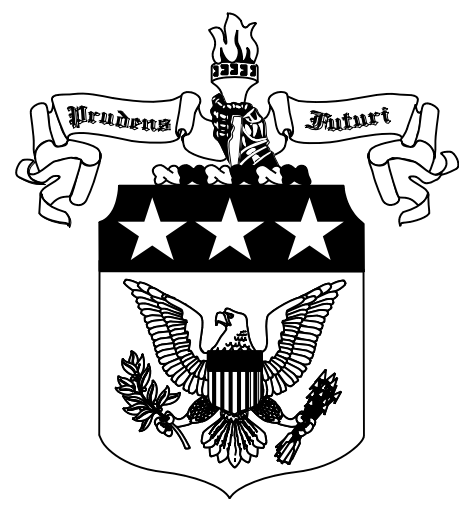


The U.S. Army War College is accredited by the Commission on Higher Education of the Middle State Association of Colleges and Schools, 3624 Market Street, Philadelphia, PA 19104, (215) 662-5606. The Commission on Higher Education is an institutional accrediting agency recognized by the U.S. Secretary of Education and the Council for Higher Education Accreditation. 


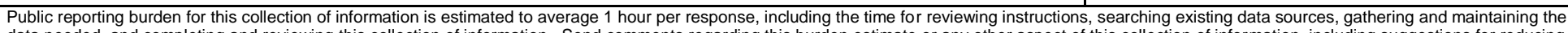

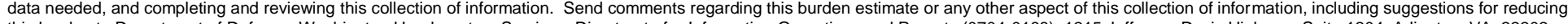

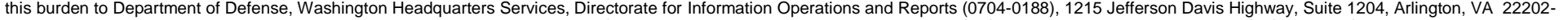

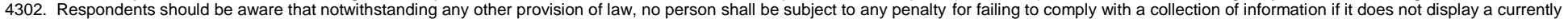
valid OMB control number. PLEASE DO NOT RETURN YOUR FORM TO THE ABOVE ADDRESS.

\begin{tabular}{l|l|l} 
1. REPORT DATE (DD-MM- $Y Y Y Y)$ & 2. REPORT TYPE & 3. DATES COVERED (FrOm - To)
\end{tabular}

24-03-2011

4. TITLE AND SUBTITLE

Strategy Research Project

Employing U.S. Navy Hospital Ships in Support of Soft Power Projection

5a. CONTRACT NUMBER

S. Navy Hospital Ships in Support of Soft Power Projection

5b. GRANT NUMBER

5c. PROGRAM ELEMENT NUMBER

6. AUTHOR(S)

Captain Michael A. Sokolowski

5d. PROJECT NUMBER

5e. TASK NUMBER

5f. WORK UNIT NUMBER

7. PERFORMING ORGANIZATION NAME(S) AND ADDRESS(ES)

Captain William G. Davis

8. PERFORMING ORGANIZATION REPORT

Senior Service Representative NUMBER

9. SPONSORING / MONITORING AGENCY NAME(S) AND ADDRESS(ES)
U.S. Army War College
122 Forbes Avenue
Carlisle, PA 17013

10. SPONSOR/MONITOR'S ACRONYM(S)

11. SPONSOR/MONITOR'S REPORT NUMBER(S)

12. DISTRIBUTION / AVAILABILITY STATEMENT

Distribution A: Unlimited

13. SUPPLEMENTARY NOTES

\section{ABSTRACT}

Over the last decade the United States has arguably slipped from the world's only true super power to a country now being challenged by China. We are seen as an aggressor by numerous world leaders and nations while China is viewed as a willing player who provides economic resources and medical aid to developing and struggling nations. The United State's seeming decline in foreign policy can be directly attributed to the employment of hard power such as military engagements in multiple countries that support non-state actors and terrorists. One way to stem the negative flow perception and gain support from these world nations is through the robust diplomacy and use of soft power projection.

\section{SUBJECT TERMS}

Humanitarian Assistance, Disaster Response, Policy Makers

\begin{tabular}{|c|c|c|c|c|c|}
\hline \multicolumn{3}{|c|}{ 16. SECURITY CLASSIFICATION OF: } & \multirow{2}{*}{$\begin{array}{l}\text { 17. LIMITATION } \\
\text { OF ABSTRACT } \\
\text { UNLIMITED }\end{array}$} & \multirow{2}{*}{$\begin{array}{c}\text { 18. NUMBER } \\
\text { OF PAGES } \\
26\end{array}$} & 19a. NAME OF RESPONSIBLE PERSON \\
\hline $\begin{array}{l}\text { a. REPORT } \\
\text { UNCLASSIFED }\end{array}$ & $\begin{array}{l}\text { b. ABSTRACT } \\
\text { UNCLASSIFED }\end{array}$ & $\begin{array}{l}\text { c. THIS PAGE } \\
\text { UNCLASSIFED }\end{array}$ & & & $\begin{array}{l}\text { 19b. TELEPHONE NUMBER (include area } \\
\text { code) }\end{array}$ \\
\hline
\end{tabular}





\title{
EMPLOYING U.S. NAVY HOSPITAL SHIPS IN SUPPORT OF SOFT POWER PROJECTION
}

\author{
by \\ Captain Michael A. Sokolowski \\ United States Navy
}

Captain William G. Davis

Project Adviser

This SRP is submitted in partial fulfillment of the requirements of the Master of Strategic Studies Degree. The U.S. Army War College is accredited by the Commission on Higher Education of the Middle States Association of Colleges and Schools, 3624 Market Street, Philadelphia, PA 19104, (215) 662-5606. The Commission on Higher Education is an institutional accrediting agency recognized by the U.S. Secretary of Education and the Council for Higher Education Accreditation.

The views expressed in this student academic research paper are those of the author and do not reflect the official policy or position of the Department of the Army, Department of Defense, or the U.S. Government. 



\section{ABSTRACT}

AUTHOR: $\quad$ Captain Michael A. Sokolowski

TITLE: $\quad$ Employing U.S. Navy Hospital Ships in Support of Soft Power Projection

FORMAT: $\quad$ Strategy Research Project

DATE: 24 March 2011 WORD COUNT: 5,131 PAGES: 26

KEY TERMS: Humanitarian Assistance, Disaster Response, Policy Makers

CLASSIFICATION: Unclassified

Over the last decade the United States has arguably slipped from the world's only true super power to a country now being challenged by China. We are seen as an aggressor by numerous world leaders and nations while China is viewed as a willing player who provides economic resources and medical aid to developing and struggling nations. The United State's seeming decline in foreign policy can be directly attributed to the employment of hard power such as military engagements in multiple countries that support non-state actors and terrorists. One way to stem the negative flow perception and gain support from these world nations is through the robust diplomacy and use of soft power projection. 



\section{EMPLOYING UNITED STATES NAVY HOSPITAL SHIPS IN SUPPORT OF SOFT POWER PROJECTION}

During the past decade U.S. influence throughout the world has declined. Arguably, U.S. global prestige has diminished because of protracted and lethal U.S. military operations in the past decade. U.S. invasions of Iraq and Afghanistan, along with propagation of the "War on Terrorism" against state and non-state actors across the globe, of U.S. militarism among some nations and have created divisions among some of the nation's staunchest allies. ${ }^{1}$ One Eurobarometer poll found "that a majority of Europeans believes that Washington has hindered efforts to fight global poverty, protect the environment, and maintain peace." ${ }^{2}$ While the U.S. has concentrated predominantly on the use of hard power to address challenging post $9 / 11$ security issues, U.S. soft power engagements and relief missions have continued. But these benevolent activities have attracted little attention at home or abroad. Even so senior U.S. policy makers, leading military officers, and some world leaders advocate a prominent role for the United States in world politics and global affairs. ${ }^{3}$ Despite its diminished reputation, the United States remains a global leader - alert an increasingly reluctant one.

China, which is striving to become a more prominent player on the world stage, would like to be viewed as a world leader and is more than willing to fill the gap that has been created by the U.S. preoccupation with combat operations in the Middle East and other areas and its reduced number of humanitarian missions. China has eagerly stepped up involvement in world affairs. Taking a page from the U.S. soft power playbook, China has provided medical and financial support to developing and 
struggling nations. ${ }^{4}$ The Chinese are beginning to use soft power in all its forms, even through its deployment of hospital ships to deliver humanitarian aid. A visible and powerful instrument of soft power is deployment of the U.S. Navy and the Chinese Peoples' Liberation Army Navy (PLAN) hospital ships to underdeveloped countries. ${ }^{5}$

Chinese soft power strategies in Southeast Asia include partnership with regional countries and collaboration with international agencies. Chinese uses of "public diplomacy", "good neighbor diplomacy", and "smile diplomacy" have enhanced China's pursuit of a compassionate hegemony. ${ }^{6}$

The Chinese are using sophisticated application of soft power to get their message out and develop relationships with Southeast nations. China has assiduously strengthened its relations with Association of Southeast Asia Nations (ASEAN) countries by means of finance, foreign aid, trade and tourism, and development of infrastructure. China's elaborate soft power diplomacy is exercise on four levels: First, it establishes political and fiscal relationships with ASEAN countries and nations through assistance and aid. Secondly, it seeks cooperative relationship through the ASEAN countries Free Trade Area (FTA). Third, it promotes pro-China cultural relationships through quasi-governmental projects. Finally, it expands its private sector influence through Chinese overseas business networks in Southeast Asia. ${ }^{7}$ However, like the United States, China projects its image of a benevolent world power by delivering medical care to the world's neediest people via Chinese hospital ships. History of Hospital Ships

In $400 \mathrm{BC}$ the Therapeia, an Athenian trireme, served as a floating hospital. Later the Romans used floating sanctuaries, called "immunes", for the same purpose. Immunes accompanied Caesar's fleet that carried Legionnaires to their destinations. 
These vessels did not engage in combat. They were accorded a special status which was recognized and respected by other nations of the time period. ${ }^{8}$ That's the concept of a hospital ship as a protected domain apart from actual hostilities and dedicated to the treatment and care of the injured, sick, and wounded was born. ${ }^{9}$ During the American Civil War, a former Confederate steamer, the Red Rover, was captured and converted to a hospital ship. On 26 December 1862, the USS Red Rover was commissioned as the first U.S. Navy hospital ship. It supported the U.S. Army's Western Gunboat Flotilla until the end of the war..$^{10,11}$

In 1898, a former passenger ship was purchased by the U.S. Army and converted over to a hospital ship, the Relief. She served off the Cuban coast during the Spanish-American War, providing care and comfort to the wounded or injured. ${ }^{12}$ Following the war, the Relief was deployed to the western Pacific to transport sick and wounded men from the Philippines back to the U.S. ${ }^{13}$ The Army transferred ownership of the Relief to the U.S. Navy in 1902, and USS Relief was commissioned. In 1908 the Relief sailed with the Great White Fleet to the Western Pacific. ${ }^{14}$

In 1907 hospital ships were entered into the Hague Convention. Articles 4, 5, \& 6 specifically specify restrictions for a hospital ships. They must be clearly marked, lighted, and painted white; their prominent display of a red cress or red crescent identifies them as hospital ships. They must provide medical assistance to all wounded personnel, regardless of their nationalities. They cannot be used for offensive military purposes and they must not interfere with enemy combatant ships and vessels. So hospital ships principal mission is to support wartime conflict by providing critical care and resuscitative life support to wounded, sick, or otherwise injured victims of the war. 
Hospital ships may be searched by a belligerent to investigate violations. ${ }^{15}$ If any of the specified restrictions are found to be violated, the ship could be designated an enemy combatant and therefore could be lawfully attacked. However, attacking or sinking a hospital ship is in direct conflict and in compliance with the Geneva Convention and would be a war crime. Armed vessels are not entitled to hospital ships' protection under the Geneva Convention. ${ }^{16}$

During World War I, the Central Powers (Germany, Hungry and Turkey) agreed voted to disregard the international law protecting hospital ships and denied their immunity from attack. During the war, Britain lost fifteen hospital ships mostly from torpedo attacks or from mines. ${ }^{17}$ During World War II, hospital ships once again made major contributions in support of the war effort and played a major role in convalescence and evacuation of wounded troops from overseas theaters of war. ${ }^{18}$ Both the Army and Navy operated hospital ships independently: The Army operated 24 hospital ships; ${ }^{19}$ and the Navy operated a total of 15 hospital ships. ${ }^{20}$

In the final phases of World War II and during the Pacific Campaign, the Navy hospital ship doctrine. Navy hospital ships were authorized to operate as mobile, definitive care treatment facilities rather than as independent transportation platforms. The USS Haven (AH-12) hospital ship was designed and built to support this operational concept. This class of hospital ships was often located just off the coast of hotly contested areas of operations. They provided safe havens for treating causalities during amphibious operations. ${ }^{21}$ Throughout the Korean War, hospital ships stayed in close proximity to combatant operations at all times. They were staffed and required to treat several hundred critical casualties and patients at one time. Several hospital ships 
rotated in and out of the Korean theater of operation during the war. Then in the spring of 1951 the USS Consolation (AH-15) was equipped with a helicopter landing pad, so operational doctrine changed again. Soon afterwards, all hospital ships had helicopter landing pads. ${ }^{22}$

During the Vietnam conflict, the USS REPOSE (AH-16) and USS SANCTUARY (AH-17), Haven class hospital ships, provided significant support to combat units. These hospital ships enjoyed a geographical advantage. Viet Nam was a narrow country with an elongated coast line, so the ships could steam up and down the Viet Nam coast twenty-fours a day, enabling them to provide immediate casualty assistance and ancillary care to all combat and non combat units. The majority of the casualties sustained during the war where flown to the ship via helicopters. ${ }^{23}$ When the Vietnam War hostilities ended in 1971, naval hospital ships returned back stateside to await further orders. In 1974 the USS Sanctuary was decommissioned. For the next two decades, the Navy had no hospital ships.

Then in the mid 1980s, two converted San Clemente-class super tankers, originally constructed to transport liquefied petroleum gas for commercial use, were purchased by the U.S. Navy and converted over to the Mercy class hospital ships. The USNS Mercy (T-AH-19) was commissioned 19 December 1986, and the USNS Comfort (T-AH-20) was commissioned 1 December 1987. Both are currently maintained in the Navy's inventory. ${ }^{24}$

Since their commissioning, these hospitals ships, have deployed and supported wartime and combat operations, delivered humanitarian assistance, and responded to disasters. They have also participated in several joint service exercises to South East 
Asia, and South and Central America. In 2001, the USNS Comfort (T-AH-20) provided medical assistance to workers and volunteers who were sifting through the debris to recover remains from the World Trade Center. The USNS Comfort recently supported recovery operations in OPERATION UNIFIED RESPONSE, in support of relief and recovery mission following the devastating earthquake that struck Haiti.

Current Hospital Ships (US and China)

The current U.S. Navy Hospital Ships in service are converted San Clementeclass supertankers' they are $894 \mathrm{ft}$ long and displace 69,000 tons. The Mercy class provides a 1000 bed hospital facility, with 12 fully equipped operating rooms, 80 beds intensive care unit, 20 beds for recovery, 400 beds for intermediate care, digital radiological services, a medical laboratory, intensive care unit, CT scan, and dental operatory facility. ${ }^{25}$ The ship is staffed by 1215 Medical Staff Members and personnel and 65 Civil Service Mariners. The Mercy class hospital ship is equipped with one of the largest trauma facilities in the U.S. it provides the full spectrum of surgical and medical services. ${ }^{26}$

The primary mission of the U.S. Navy Mercy class hospital ships is to provide emergency on-site medical care for U.S. combat forces deployed in support of war efforts or other combat or contingency operations. The secondary mission is to provide full U.S. medical services and support in support of HA missions, Disaster Response (DR) operations, and Goodwill exercises. ${ }^{27}$ In August 2006, China launched its first hospital ship that was designed and constructed from the keel on up, operational in 2008. The Type 920 Anwei Class Hospital ship is $530 \mathrm{ft}$. in length, and displaces 23,000 tons. It has a 600 bed capacity, operating rooms, laboratories, a pharmacy, and crew quarters. It has a flight deck and a hanger deck to support two medium size 
helicopters used to transport medical teams and patients to and from the ship. Based on intelligence estimates, the Type 920 hospital ship can accommodate a crew of 600 medical department personnel and 200 all-purpose crew members. ${ }^{28}$ This ship was design to provide medical assistance and treatment for military personnel in a war zone, specifically in support of amphibious operations. ${ }^{29}$ This ship will also give the PLA Navy a fast and flexible surgical medical sea asset that can support HA and DR missions. ${ }^{30}$ $\underline{\text { Soft Power }}$

“Joe Nye defines 'soft power' as a country's ability to influence events through persuasion and attraction, rather than military or financial coercion". ${ }^{31}$ Soft power can affect others' behavior and influence events. ${ }^{32}$

So soft power enables a nation to change another nation's or groups position to achieve the power-wielding nation's objective. On the contrary, hard power utilizes military force and/or economic means to impose a nation's will on another to achieve an objective. ${ }^{33}$ But, hard power is not always an effective or wise political or strategic course of action. Projection or coercion can be a useful method to influence other states to change direction. But the application of hard power usually involves payments ("carrots") or threats ("sticks"), and often a country can achieve its goals by co-opting people rather than coercing them - in effect, by exercising a means to enhance soft power. ${ }^{34}$

Soft power is much more than "image, public relations, and popularity." It constitutes real power and enables a country to gain specific objectives. U.S. political ideals, manifest in the Marshal Plan, favorably influenced Europe after World War II, by enabling the United States to stymie Soviet expansion into Europe. Likewise, social 
networking and satellite television stations currently build support in Iran for Western political ideals and economic practices. ${ }^{35}$

A country possesses more soft power when its culture, institutions, and values are respected and admired around the world. The global popularity of U.S. culture is a strong component of U.S. soft power. Used effectively, it could benefit the United States. ${ }^{36}$

The Obama Administration has recognized that the U. S. and the world face challenging situations. The United States must meet critical foreign policy challenges over the next decade. It is currently involved in two wars. It must respond to a number of regional conflicts across the globe. Its economy is battered by a worldwide economic crisis. It is seeking to eliminate weapons of mass destruction. Climate change, pandemic disease, worldwide poverty, food insecurity, limited potable water resources, and terrorism present a range of problems that are attesting U.S. global leadership. ${ }^{37}$

At times our leaders must rely on of military force to protect our citizens, our national interests, and to assist our allies. However, there are times when the employment of diplomacy can be just as effective in creating peaceful and stable conditions throughout the world. Smart power enables us to recognize and efficiently project military force or diplomacy effectively when needed. Our national leaders must strive to use all the tools at our disposal in a cohesive method. ${ }^{38}$

'Secretary of State, Hillary Rodham Clinton was quoted to have said' 'We must use what has been called smart power: the full range of tools at our disposal diplomatic, economic, military, political, legal, and cultural - picking the right tool, or combination of tools, for each situation." 39 
To be successful U.S. policy makers must reverse the decline of U.S. influence throughout the world and strengthen national security through - or a combination of military power and economic strength, especially with investments in soft power projection. Our global image will improve if our leaders exercise smart power by taking the following initiatives: ${ }^{40}$

1. Refresh alliances, partnerships and institutions.

2. Increase the development and the role of U.S. foreign policy to align U.S. interests with aspirations of people from around the world.

3. Work at winning the 'hearts and minds' of foreign citizens through long-term, relationships in the exercise of public diplomacy.

4. Support economic assimilation and increase the benefits of trade for all people.

5. Assume a leadership role in knowledge, technology, and innovation specifically by addressing climate change and energy uncertainty. ${ }^{41}$

By taking these initiatives, and engaging in productive dialogue among our adversaries and friends, by soliciting support from standing alliances, and by creating new alliances, the United States can gain greater global respect and invest in humanity everywhere. $^{42}$

\section{The Decline of American Soft Power}

In recent years an increase in Anti-Americanism across the world has significantly impacted America's ability to promote soft power. ${ }^{43}$ In a recent Gallup International Poll cited in an article in 'Foreign Affairs', 29 countries surveyed worldwide responded that Washington's policies have had a negative effect on the way they view America the United States. ${ }^{44}$ 
The United States cannot effectively to deal with the worldwide terrorist threat without support and assistance from other countries, especially its traditional allies. However, the extent of these countries cooperation and support often depends on the U.S. appeal. ${ }^{45}$ In Indonesia, which has the world's largest Islamic population, 75 percent of the population had a favorable view of the U.S. in 2000. But, in 2003, only three years later, that had regressed to just 15 percent. ${ }^{46}$

If the United States is going to prevail in the War on Terror, it is imperative that U.S. policy-makers, diplomats, and military leaders foster stronger international relationships and enter into more cooperative agreements. Countries such as Indonesia and other non-traditional state actors should be key partners. The United States must nurture relationships with such countries in order to regain its global prestige and to promote effective global leadership. ${ }^{47}$ Hospital Ships: Soft Power Assets

Current hospital ships were built to support combat operations. However, over the past decade their roles have continued to shift as they have contributed to Humanitarian Assistance (HA) and Disaster Response (DR) operations across the globe. They have been used in support of U.S. Medical Diplomacy, a termed coined by the Bush - 43 Administration's Health and Human Services Secretary, Tommy Thompson, who declared, "What better way to knock down the haltered, the barriers of ethnic and religious groups that are afraid of America, and hate American, than to offer good medical policy and good health to these countries." ${ }^{48}$

The U.S. uses of Medical Diplomacy to win the hearts and minds of people in the Middle East, Africa, Asia, and various other areas of the world that are a superb example of smart power. ${ }^{49}$ 


\section{Next Generation US Navy Hospital Ship}

The COMFORT and MERCY hospital ships are twenty-five years old. Their operating budget and life cycle maintenance cost should be a consideration when budgeting for replacement platforms. ${ }^{50}$ The Navy, DoD, and DoS will need to work together and develop a shipbuilding construction plan to include design, development and delivery program, and deployment options, that could then may be presented to Congress in an effort to appropriate funding. This must be a key Navy priority since it will be necessary to plan to spend billions of dollars to procure this type of ship. The next generation hospital ships should be equipped with state-of-the-art, fixed medical equipment, portable medical rapid-response equipment, and preventive medicine equipment. They must be able to accept patients from the sea, from small craft, and from aviation assets including helicopters, tilt rotor, and vertical take-off and landing (VTOL), type platforms. These ships should be designated and properly marked as hospital ships in accordance with the Geneva Convention. Or they could be Navy amphibious assault ships that can easily gain access to the littorals and other restricted shallow water ports. These ships ought to be designed and constructed with amphibious design characteristics. They should be outfitted with specific medical contingency packages so they can conduct HA and DR missions through-out the world visiting countries who inhabitants and indigenous people are in need or require medical assistance.

During the designing process for the next generation hospital ship an area in need of major improvement is that involving patient transportation. The T-AH Mercy class ships receive the majority of their patients from helicopters and are limited to two helicopters on deck at a time. They also have an antiquated patient receiving/transport 
system located in the after area of the ship on the port and starboard side at the sallyports. This system is slow and limited in numbers of patients being moved at a time, and cannot be used during rough seas or inclement weather. The Mercy class does not have a well-deck built into the ship, and therefore patients cannot gain access from a landing craft or Landing Craft Air Cushion (LCAC) type vessels. The next generation hospital ship needs to include a well deck to increase patient access and movement of medical transportation of staff and equipment. ${ }^{51}$

To be effective strategically these ships must be forward deployed or homeported in geographical regions of the world that are considered high risk or potential threat areas enabling a quick response. They need to be smaller and faster than current ships, capable of high speeds to be able arrive on station or to a disaster in the first 24 hours. They must also be able operate in close proximity to the beach and gain access to shallow, and possibly littered, ports and estuaries. ${ }^{52}$

The location and proximity of the majority of the world populations to the coastline and littorals require that the next generation hospital ship has a shallow draft so it can navigate the littorals and able gain access to smaller unnatural harbors. Current Navy platforms in use in the naval service are deep draft vessels that require deep water ports. To gain access to areas without deep water ports these large ships must anchor some distance from the shore. This extends the logistical lines of communications. It then takes more time to deliver quality medical care, which at times may be furthered hindered by inclement weather and high seas. The Brazilian Navy operates several hospital ships on the Amazon and its tributaries. It has developed a hospital ship that is a smaller, has a shallow-draft, and can provide quality medical care 
to the inhabitants of Amazon River and the interior regions. ${ }^{53}$ The U.S. Navy should consider this Brazilian model as it designs the next generation of hospital ship.

The ship building program for this class of hospital ship will be time consuming, expensive and will require current medical technologies, which are quite large in size, heavy in weight, and expensive to maintain. These would need to be downsized, reduced in weight and include reduced operating costs, challenging the medical diagnostic and bio-mechanical manufacturers to meet specific requirements, while at the same time allowing shipboard construction of a smaller, faster, and more flexible platform. By keeping design and development costs down an increased number of hospital ships could be built for the navy to help meet the future strategic requirements and needs.

Regularly scheduled deployments of hospital ships overseas around the globe conducting humanitarian assistant missions, good will partnerships, or when responding to natural or man-made disasters will help to improve the over-all perception of the U.S. and in-turn help provide greater support in our efforts on the War on Terror.

The Littoral Combat Ship (LCS), currently being added to the navy fleets could also be used as an option or in direct support to a hospital ship, especially when responding to humanitarian assistance or disaster response missions. These ships were specifically designed with speed and shallow draft capabilities in mind for operating in the littorals and near shore environments. A stern gate has been added to the ship design to allow multi-mission capabilities and flexibility in planning for deployment missions. In the event of a disaster this class ship could be the answer for quick responses in a shorter period of time. ${ }^{54}$ 
A module designed specifically for disaster response missions, pre-assembled and stocked with medical supplies, equipment, and fixed medical treatment rooms and facilities could be moved in to position into the littoral combat ship well deck via the stern-gate. ${ }^{55}$ This vessel could meet the specific requirement for speed, agility, and shallow draft condition but, does not possess the ability to conduct sustained medical treatment procedures or perform surgical operations. This type of vessel would offer a supplement to an actual hospital ship when needed, possessing humanitarian service and medical capabilities (a medical support staff consisting of 24 highly trained physicians, nurses and hospital corpsman will be assigned to accompany the LCS), affording policy makers with another option in support of soft power projection, helping to improve relations with global allies, coalition partners, and possibly helping win over distrustful foreign countries throughout the world that have traditionally seen the U.S. as an aggressive nation, or have opposed policies and have developed a negative opinion of the U.S.

It will be an extremely challenging undertaking for the U.S. to have this negative perception changed. The DoD, DoS and the U.S. Navy need to develop long term cooperative agreements with other nations to develop, foster and build secure and confidant relationships and over time supporting ideals.

\section{$\underline{\text { Recommendation \& Analysis of Future Operations }}$}

If the U.S. is going to regain its place on the world stage as the leader of the free world, senior policy makers can utilize soft power in their efforts to restore U.S. prestige and other nations. The current budget planned for the next five to ten years will increase only slightly. So DoD senior leaders are challenged to make some difficult decisions regarding acquisitions of weapons systems and platforms. 
They will have to decide whether or not to invest in the next generation hospital ship. This generation ship could very well be a soft power asset and a tool to assist the U.S. in regaining prominence on the world stage. It will require long-range strategic plans that are coordinated through the inter-agency members and among political leaders should show how to effectively employ it in support of soft power projection missions. A small fleet of hospital ships would provide an excellent instrument of power. It would cost substantially less than some of the current projected weapons programs for development and deployment. ${ }^{56}$

Planners should consider the options of the Navy's gray hull amphibious assault ships. These vessels can be used to support either medical deployments in humanitarian assistant or disaster response missions; they can also be used to support Marine amphibious operations and landing forces. These ships have a distinct advantage in their ability to deploy quickly. They are able to gain access into ports that have a constrained draft (shallow port) or limited in size, unlike the present Mercy class hospital ships. Currently these ships can receive patients transported by air. But these ships have a major drawback. They have only combat definitive medical care capabilities and staffs this limits their ability to deliver definitive care over a long period of time. The medical staff that deploys with these ships is tailored to support the Marine Corps mission. They are not staffed and are therefore limited in their capabilities to support humanitarian and disaster relief operations. More importantly these ships are classified as combatants, so they are not protected under the articles of the Geneva Convention. 


\section{Next Generation Staffing Considerations}

Currently the majority of medical staff members assigned to the Navy hospital ship platforms (USNS Mercy and USNS Comfort) come from Navy Medical Treatment Facilities (MTF) located at navy bases and facilities across the continental United States (CONUS) and outside the contiguous United States (OCONUS). Over the last decade the United States has deployed hospital ships to respond to various disasters. During recent deployments to the Indian Ocean, they responded to the devastating earthquake and Tsusumi in 2004. ${ }^{57}$ Operation Continuing Promise, they contributed to Humanitarian Assistance missions to South and Central America in 2009. Recently, the Comfort deployed in support of relief operations for the 2009 Haitian earthquake. Navy staff augmented by other military medical staff personnel and NGO's, have performed admirably in these soft power missions. ${ }^{58}$

To operate effectively, at an efficient capacity, hospital ships can be staffed in the following ways, depending on the type of mission or deployment and its objective. ,

- A joint military contingent staff made up of entirely Department of Defense (DoD) active duty and reserve medical service members, and Military Sealift Command (MSC) support personnel who are deployed in support of hostile or combat operations, carrying out a Noncombatant Evacuation Order (NEO) or an immediate assistance mission.

- A joint military contingent medical staff, DoD civilian counterparts, interagency partners, and Non Government Organization (NGO) personnel who would deploy in support of an emergent Humanitarian Assistant (HA) missions in response to man-made or natural disasters. 
- A joint military contingent medical staff, DoD civilian counterparts, NGOs, interagency partners, coalition partners, and international agencies that deploy in support of Humanitarian-focused assistance missions, Disaster Response and civic assistance support missions to promote goodwill.

Currently the hospital ships are staffed and augmented via MTF's located in CONUS but, to be successful and shorten response time and increase mission effectiveness, the navy could outfit the new class ship with a permanent crew made-up and staffed by one or a combination of the three proposed scenarios. Currently military medicine does not possess enough manpower or assets to man these ships permanently (full time). However, if the DoD, Office of Secretary of Defense (OSD), Health Affairs, and Department of State (DoS) worked together with NGO's a dedicated medical staff could be assigned to the ship and would help improve response time and mission effectiveness. The assigned medical assets from the various agencies and services would help to improve working relationships between all government and nongovernment agencies, and partners, offer a comprehensive and trained medical staff, and provide a rapid and flexible platform able to respond in times of humanitarian missions or natural disaster. ${ }^{59}$

Conclusion

Soft power has distinct advantages over hard power. Soft power is a much more cost effective option over a long period of time. Typically it does take an extended amount of time for them to be successful; in some cases years or decades to achieve the strategic goals developed by policy makers. On the other hand, hard power quickly yields visible results. However, it is also much more expensive and is usually extremely costly to the nations involved both in blood and treasure. Further social networking 
makes hard power less attractive and less successful. The strongest military force in the world cannot ameliorate environmental degradation, endemic diseases, starvation, or pandemic influenza. The explosion in technology minimizes hard power effectiveness. $^{60}$

Furthermore, the increased number of world democracies makes populations more difficult to influence. ${ }^{61}$ To help develop a strategy of soft power projection or smart power it is therefore pertinent that the Department of Defense, National Security Council, and the Department of State, develop a strategy which includes a set of tools (ways and means) to effectively employ soft power. One such tool should be the next generation hospital ship. This asset would fully support soft power and make the most use of limited resources. They will need to be built from the keel up, included state of the art medical equipment and be of sufficient number to support soft power projection through scheduled rotational deployments.

Unscheduled deployments would also need to be factored in to long term planning operations in response to natural or manmade disasters. Planning for regular scheduled deployments and responding swiftly to nations in need of assistance, the U.S. could help bring stability to those regions, develop new friendships by winning the hearts and minds, in regions of the world where it is needed and where the U.S. soft power has declined over the last twenty years.

Using strategic leader foresight and competencies, and working with other government and non government agencies, those in academia, and other nations, the U.S. can improve relations and increase a positive perception of America and develop stronger relationships and win world approval. A strategic plan that will allow the 
country to practice its ends, ways, and means through deployment of U.S. navy hospitals ships and soft power projection will help America achieve its short term and strategic goals and bring greater stability to the world.

The deployment of U.S. Navy hospital ships in support of regularly scheduled humanitarian visits and bilateral exercises to nations who would benefit from advanced medical assistance and support could help facilitate positive U.S. impressions; and once again achieve the prominence as the leader of the free world. U.S. policy makers, senior military and DoS leaders could achieve success in future foreign policy through the deployment of soft power projection. By engaging in strategic soft power projection the U.S. will demonstrate to the world community and host nations that we are once again ambassadors of goodwill and true leaders of the free world.

\section{Endnotes}

${ }^{1}$ The Decline of America's Soft Power Why Washington Should Worry, Foreign Affairs Volume 83 No. 3, http://staff.maxwell.syr.edu/cgerard (accessed January 28, 2011).

${ }^{2}$ lbid.

${ }^{3}$ How China Mimics US Soft Power, The Diplomat, http://the-diplomat.com/2010/11/09/ how-china-mimics-us-soft-power/ (accessed February 9, 2011).

${ }^{4}$ Ibid.

${ }^{5}$ lbid.

${ }^{6}$ H. H. Michael Hsiao and Alan Yang, Soft Power Politics in the Asia-Pacific: Chinese and Japanese Quests for Regional Leadership, http://www.japanfocus.org/-Michael-Hsiao/3054 (accessed March 5, 2011).

7 lbid.

${ }^{8}$ Hospital Ship History, Globalecurity.org, http://www.globalsecurity.org/military/systems/ ship/ah-ohistory.htm (accessed January 12, 2011).

${ }^{9}$ Ibid 
${ }^{10}$ David P. Gray, MANY SPECIALTIES, ONE CORPS, A pictorial history of the U.S. Navy Medical Service Corps, Copyright 1997 by Department of the Navy, p.22

${ }^{11}$ Southernmost Illinois History, http://southernmostillinoishistory.net/redrover.htm, (accessed January 7, 2011).

${ }^{12}$ Naval History \& Heritage Command, USS Relief (1908-1919), http://www.history.navy.mil/photos/sh-usn/usnsh-r/relief2.htm (accessed February 2, 2011).

${ }^{13}$ Ibid.

${ }^{14}$ Ibid.

${ }^{15}$ Convention (II) for the Amelioration of the Condition of Wounded, Sick and Shipwrecked Members of Armed Forces at Sea, August 12, 1949, http://avalon.law.yale.edu/20th_century/ geneva06.asp (accessed February 12, 2011).

${ }^{16}$ Ibid.

${ }^{17}$ Hospital Ship History, Globalecurity.org, http://www.globalsecurity.org/military/systems/ ship/ah-history.htm (accessed January 12, 2011).

${ }^{18}$ Army Transport Service Hospital Ships, http://www.usmm.org/hospital.html (accessed January 31, 2010).

${ }^{19}$ Ibid.

${ }^{20}$ WW II Research Centre; WW 2 Hospital Ships, www.med-dept.com/hosp_ships.php (accessed January 31, 2011).

${ }^{21}$ Hospital Ship History, Global Security.org, http://www.globalsecurity.org/military/ systems/ship/ah-history.htm (accessed February 28, 2011).

22 Ibid.

${ }^{23}$ USS Repose History, http://ussrepose.org/history.htm (accessed March 6, 2011).

${ }^{24}$ U.S Navy Military Sealift Command http://www.msc.navy.mil/factsheet/ USNSMercyFactSheet.pdf (accessed March 7, 2011).

${ }^{25}$ U.S. Navy Military Sealift Command, USNS Comfort (TA-H -20) Hospital Ship, Ship characteristics, http://www.defense.gov/home/features/2010/0110_haiti/images/ USNSComfortFactSheet.pdf (accessed February 17, 2011).

${ }^{26}$ Ibid.

${ }^{27}$ Ibid.

${ }^{28}$ Type 920 Anwei-class Hospital Ship http://www.globalsecurity.org/military/world/china/ type-920.htm (accessed February 26, 2011). 
${ }^{29}$ Ibid.

${ }^{30} \mathrm{lbid}$.

31 "Soft Power - The Means to Success in World Politics", UCLA International Institute, http://www.intenational.ucla.edu/article.asp?pparentid=34734 (accessed January 22, 2011).

${ }^{32}$ Ibid.

${ }^{33}$ Ibid.

${ }^{34}$ Joseph S. Nye, Jr. and David A. Welch, Understanding Global Conflict and Cooperation, An Introduction To Theory And History, Eight Edition, p. 40.

${ }^{35}$ Joseph Nye Soft Power, foreign policy, international diplomacy, war on terror, Book Review http://www.futurecasts.com/book/review (accessed March 3, 2011).

36 "Soft Power - The Means to Success in World Politics", UCLA International Institute, http://www.intenational.ucla.edu/article.asp?pparentid=34734 (accessed January 31, 2011)

${ }^{37}$ American "Smart Power": Diplomacy and Development Are the Vanguard, U.S. Department of State, http://www.state.gov/r/pa/scp/fs/2009/122579.htm (accessed 3 March 2011).

${ }^{38}$ Ibid.

39 "Nye/Armitage Report: Steps Toward Restoring U.S. Influence", Belfer Center for Science and International Affairs, John F. Kennedy School of Government, Harvard University, http://belfercenter.ksg.harvard.edu/publication/18101/nyearmitage_report.html (accessed March $5,2011)$.

${ }^{40}$ lbid

${ }^{41}$ Ibid.

${ }^{42}$ Ibid.

${ }^{43}$ The Decline of America's Soft Power, Foreign Affairs, http://www.foreignaffairs.com/

articles/59888/joseph-s-nye-jr/the-decline-of-americas-soft-power (accessed February 9, 2011).

${ }^{44}$ Ibid.

${ }^{45}$ lbid.

${ }^{46}$ Squandering the U.S. 'Soft Power' Edge, http://www.nafsa.org/_file/_/ frontlines_jan_feb.pdf (accessed March 5, 2011).

${ }^{47}$ Ibid.

${ }^{48}$ Let's Have a Fleet of 15 Hospital Ships, http://blog.usni.org/2010/01/21/lets-have-a-fleetof-15-hospital-ships/ (accessed February 9, 2011 
${ }^{49}$ Ibid.

${ }^{50}$ Eric J. Labs, CBO Testimony, Current and Projected Shipbuilding Programs, http://www.cbo.gov/ftpdocs/90xx/doc9045/Shipbuilding_Main_Text.1.1.shtml (accessed 20, March 2011).

${ }^{51}$ Operational Medicine 2001, T-AH (Hospital Ship), http://www.brooksidepress.org/ Products/OperationalMedicine/DATA/operationalmed /Transportation/Ships/TAH.htm, (accessed 20, March 2011).

${ }^{52}$ Eric J. Labs, CBO Testimony, Current and Projected Shipbuilding Programs, http://www.cbo.gov/ftpdocs/90xx/doc9045/Shipbuilding_Main_Text.1.1.shtml (accessed 20, March 2011).

${ }^{53}$ Hospital ship: Facts, Discussion Forum, and Encyclopedia Article, http://www.aboluteastronomy.com/topics/Hospital_ship (accessed January 14, 2011)

${ }^{54}$ Rhumb Lines, Littoral Combat Ship, http://www.navyreserve.navy.mil/Rhumb\%20Lines/ Littoral\%20Combat\%20Ship\%20LCS\%2030\%20DEC\%2010.pdf, 2010/12/30 (accessed 21 March 2010).

${ }^{55}$ Ibid.

${ }^{56}$ Let's Have a Fleet of 15 Hospital Ships, http://blog.usni.org/2010/01/21/lets-have-a-fleetof-15-hospital-ships/ (accessed February 9, 2011).

${ }^{57}$ United States Department of Defense, 2005 Year in Review, http://www.defense.gov/ home/features/2006/2005yearinreview/article2.html (accessed January 12, 2011)

${ }^{58}$ United States Southern Command, Partnerships for the Americas, http://www.southcom.mil/appssc/factfiles.php?id=103 (accessed January 12, 2011)

${ }^{59}$ Designing The Next Hospital Ship: Lessons From Haiti, Designing The Next Hospital Ship: Lessons From Haiti (accessed 20, March 2011).

60 Joseph S. Nye, Jr, Soft Power and Command, Partnerships for the Americas, http://www.southcom.mil/appssc/factfiles.php?id=103 (accessed January 12, 2011)

61 lbid. 